\title{
STRUKTUR ADHOKRASI DAN MATRIKS SEBAGAI SOLUSI ATAS KRITIK BIROKRASI DI LEMBAGA PENDIDIKAN
}

\author{
Endah Winarti ${ }^{*}$ \\ 1 Institut Agama Islam Darullughah Wadda'wah Pasuruan
}

\begin{abstract}
Technology and globalization's challenge, have demanded public service institutions, including educational institutions, continue to innovate and improve themselves in preserving with the times. On the other hand, the bureaucracy used today is less flexible and inefficient, so that it raises a lot of criticism, which shows the powerlessness of the bureaucracy to face that challenge. These criticisms present a new form: adhocracy and organizational matrix, which gives flexibility in the organizational structure. The article proposes to present solutions to overcome bureaucratic criticism by integrating adhocracy and matrix organization in educational institutions bureaucracy. The integration of the three forms of organizational structure is expected to make educational institutions flexible and efficient to be able to resist the challenges of the times.
\end{abstract}

Keywords: bureaucracy, adhocracy, matrix, education institution

\begin{abstract}
Abstrak: Tantangan kemajuan teknologi dan globalisasi, telah menuntut lembaga-lembaga layanan publik, termasuk institusi pendidikan, untuk terus berinovasi dan memperbaiki diri mengikuti perkembangan zaman. Disisi lain, birokrasi yang digunakan saat ini kurang fleksibel dan inefisiensi hingga memunculkan banyak kritik, yang menunjukkan ketidakberdayaan birokrasi jika berhadapan dengan tantangan zaman. Kritik-kritik tersebut menghadirkan bentuk baru: adhocracy dan organisasi matriks, yang menghadirkan fleksibilitas dalam struktur organisasi. Artikel bertujuan menghadirkansolusi mengatasi kritik birokrasi dengan
\end{abstract}

*Korespondensi Penulis: endahwinarti002@gmail.com 
mengintegrasikanadhokrasi dan organisasi matriks dalam birokrasi di lembaga pendidikan. Integrasi ketiga bentuk struktur organisasi tersebut, diharapkan dapat menjadikan institusi pendidikan menjadi fleksibel dan efisien untuk dapat bertahan dalam berbagai tantangan zaman.

\section{Kata Kunci: Birokrasi, Adhokrasi, Matriks, institusi pendidikan}

\section{A. Pendahuluan}

Sejak diperkenalkan oleh Weber sebagai sebagai sebuah fitur modernitas yang penting di akhir abad ke-19, birokrasi mulai berkembang menyebar digunakan di lembaga-lembaga berskala besar di dunia, utamanya pemerintah dengan pelayanan publik.1Dengan ciri utamanya pada kekuasaan hirarkhi, pembagian kerja dan spesialisasi, prosedur serta efisiensi, Weber memperkenalkan birokrasi sebagai pendongkrak sistem organisasi yang luar biasa, yang akan memberikan sistem manajemen yang adil dengan mengurangi kecenderungan manusia dalam membuang waktu, dan praktik diskriminasi.

Namun, berbanding tebalik dengan yang dimaksudkan Weber, birokrasi kini justru sering diasumsikan dengan urusan berbelit-belit, prosedur yang panjang dan memakan waktu, penuh KKN, struktur yang terlalu besar dan hal-hal negatif lainnya. Caiden² bahkan menyebutkan adanya 175 patologi birokrasi (bureaupathologies) yaitu penyakit yang muncul dalam pelaksanaan birokrasi. Para pemimpin dan kalangan profesional mendapati bahwa birokrasi tidak dapat digunakan dalam mengatur lembaga, utamanya dalam kondisi lingkungan yang membutuhkan inovasi tinggi. Spesialisasi dan hirarkhi harus dipangkas karena telah membatasi ruang gerak mereka untuk berinovasi. Kritik lain datang dari

\footnotetext{
${ }^{1}$ Beetham, David. Bureaucracy. (U of Minnesota Press, 1996).

${ }^{2}$ Gerald E Caiden. "What really is public maladministration?." Public Administration Review, (1991): 486-493.
} 
Heckscher dan Donellon ${ }^{3}$ yang mengemukakan pentingnya bentuk organisasi masa depan yang ia sebut dengan post bureaucratic organization, yang tidak hanya menempatkan kekuasaan (powering) sebagai satu-satunya alat dalam menjalankan organisasi, tetapi juga dibutuhkan kewenangan melalui persuasi dan dialog atau yang dikenal dengan istilah pemberdayaan (empowering).

Pada sektor pendidikan, birokrasi Weber telah diadopsi dan digunakan sangat lama sebagai struktur administratif universal dalam menjalankan manajemen lembaga pendidikan sehari-hari, di berbagai penjuru dunia. meski demikian, tetap saja melahirkan kritik atas penggunaan birokrasi dilingkungan pendidikan yang melahirkan praktik diskriminasi dan ketidakadilan sistemik. ${ }^{4} \mathrm{Hal}$ ini seolah menunjukkan bahwa birokrasi telah gagal dan harus segera digantikan dengan sistem tatanan sosial yang baru, yang lebih kini sesuai dengan kebutuhan zaman.

Pada perkembangannya, para ahli mencoba memberikan alternatif dengan menghadirkan struktur baru yang dapat mengatasi persoalan-persoalan yang ada. Dalam hal ini Mitzberg5 kemudian memperkenalkan satu struktur yang disebut adhocracy. Kekuatannya dalam menghilangkan hirarkhi, dianggap akan memberikan keleluasaan kepada para kaum profesional untuk memecahkan masalah dengan inovasinya masing-masing. Di samping juga dikenal salah satu bentuk struktur organisasi dengan istilah organisasi matrik, yang mengkombinasikan hirarkhi dengan desentralisasi (pembagian kewenangan).

Hadirnya dua bentuk struktur baru tersebut menimbulkan pertanyaan, haruskah birokrasi yang selama ini telah digunakan di dunia pendidikan digantikan dengan bentuk struktur baru tersebut, ataukah terdapat alternatif lain? hlm. 4

${ }^{3}$ Dalam Miftah Thoha. Birokrasi \& Politik. (Jakarta: PT RajaGrafindo Persada, 2007),

${ }^{4}$ Stephen $\mathrm{K}$ Jull. "Locating gender bias and systemic discrimination in public schooling bureaucracy." Alberta journal of educational research 48.1 (2002): 47.

${ }^{5}$ Henry Mintzberg. "Structure in 5's: A Synthesis of the Research on Organization Design." Management science 26.3 (1980): 322-341. 


\section{Endah Winarti}

Mengingat birokrasi bagaimanapun juga masih menjadi pilihan struktur yang masih dianggap tepat untuk diterapkan dalam dunia pendidikan. Artikel ini berupaya menghadirkan jawaban atas persoalan tersebut dengan mengungkap kemungkinan bagaimana kedua bentuk struktur (adhokrasidan matriks) dapat digunakan untuk memecahkan persoalan yang muncul dalam pengimplementasian birokrasi di dunia pendidikan.Dengan demikian, organisasi pendidikan dapat berjalan optimal, tercapai tujuan organisasinya serta mampu mengatasi berbagai hambatan dari lingkungan yang terus berubah.

\section{B. Struktur Organisasi: Birokrasi, Adhokrasi, dan Matriks}

Struktur organisasi merupakan bagian dari aspek-aspek teori organisasi yang penting untuk dibahas. Menurut Robert H. Miles sebagaimana dikutip Hardjito $^{6}$ struktur disebut juga desain organisasi adalah pengaturan antar hubungan bagian-bagian dari komponen dan posisi dalam suatu organisasi. Struktur organisasi pada hakikatnya merupakan sebuah bentuk tatanan yang menyeluruh dari unsur lingkungan yang dapat saja dipengaruhi oleh lingkungan yang memiliki perbedaan kondisi, jenis dan ukuran suatu target yang hendak disasar. Dalam pada itu, bagan struktur organisasi menurut kebiasaan dapat berupa chart yang menampilkan keseluruhan proses yang berlaku secara hirarki dan terdefinisinya seluruh proses yang disepakati dalam organisasi tersebut diantaranya: ${ }^{7}$

(1) Gambaran tersebut mengkaji tentang pembagian tugas dan tanggung jawab yang dibebankan kepada anggota dan pemangku kebijakan untuk dijalankan secara individu dan kolektif.

(2) Gambaran mengenai hubungan roses laporan yang telah ditetapkan oleh organisasi secara hirarki dengan adanya kendali dari pimpinan untuk mendapat persetujuan secara efektif.

6 Dydit Hardjito, Teori Organisasi dan Teknik Pengorganisasian, (Cet. III, Jakarta: RajaGrafindo Persada, 1995), hlm. 25.

${ }^{7}$ Ibid., hlm. 21-22 
(3) Gambaran berisi penjabaran tugas yang menampilkan segala bentuk tugas yang diemban dan diselesaikan dalam target tertentu.

(4) Gambaran yang berisi ketetapan sistem dan hubungan dalam berorganisasi yang memungkinkan adanya komunikasi antar anggota serta pelaksanaan integrasi yang bersifat baik horizontal maupun vertikal.

Dari komponen-komponen tersebut, maka dapatlah dimengerti mengapa dalam organisasi dibutuhkan sebuah struktur yang jelas. Tanpa struktur, akan terjadi kebingunan dan bahkan tumpang tindih perintah dan tanggung jawab. Beberapa bentuk struktur yang berkembang antara lain:

\section{Birokrasi}

Birokrasi adalah organisasi besar dimana orang-orang didalamnya memilikipengetahuan tertentu yang terorganisir dalam sebuah hirarki yang jelas, dan masing-masing memiliki misi yang spesifik. ${ }^{8}$ Ilmuan yang sangat berjasa dalam memperkenalkan model organisasi birokratis adalah Max Weber, yang mencoba melukiskan sebuah organisasi yang ideal-organisasi yang secara murni rasional dan yang akan memberikan efisiensi operasi yang maksimum. ${ }^{9}$ Menurut Max Weber, pendekatan yang lebih luas terhadap organisasi dan strukturnya adalah melalui perspektif sosial dan historikal, sehingga Weber mengembangkan model birokrasi ideal normatifyang terefleksi dengan konsep karyawan publik. Birokrasi terdiri dari karyawan publik profesional yang netral sehingga hirarki organisasi dapat berfungsi selancar dan seefektif mungkin. Birokrasi adalah struktur administratif khusus yang berdasar pada otoritas yang berorientasi pada hukum dan aturan.

\footnotetext{
8 Peter M. Blau, Bureaucracy in Modern Society, (Crown Publishing Group/Random House, 1956)

${ }^{9}$ Stephen P. Robbins, Teori Organisasi: Struktur, Desain dan Aplikasi, (Jakarta: Arcan, 1994), hlm. 337
} 
Weber mempertegas dalam teorinya bahwa satu-satunya cara bagi masyarakat modern untuk mengoperasikan secara efektif konsep ideal tersebut di atas ialah dengan mengorganisasikan spesialis-spesialis birokrasi yang fungsional dan terlatih. Hal ini sesuai dengan yang dikemukakan oleh LeMay, ${ }^{10}$ bahwa sebagai organisasi yang cenderung semakin besar, membutuhkan pembagian kerja yang lebih kecil atau bersifat khusus. Karakteristik dari birokrasi ideal antara lain:11 (1) Distribusi kerja yang mapan antara anggota-anggota organisasi; (2) Hirarki administratif; (3) Sistem yang berorientasi aturan, yang menggambarkan kinerja; (4) Pemisahan kepemillikan pribadi dan hak-hak organisasi; (5) Seleksi staf menurut kualifikasi teknis pekerjaan melibatkan jenjang karir. Tindakan tujuanrasional merupakan bentuk optimal perilaku. Bertindak pemenuhan tujuan secara rasional merupakan pendekatan yang ideal yang memperhatikan tiga hal yaitu tujuan, makna, dan efek samping. Karakteristik ideal ini, sampai saat ini belum sepenuhnya dapat diimplementasikan di Indonesia sebagaimana yang diharapkan pencetusnya.

Weber berpandangan tentang konsep birokrasi yang menurutnya terbagi menjadi tiga elemen pokok sebagai berikut: (1) instrumen teknis yang berlaku dalam lembaga pendidikan itulah yang disebut sebagai birokrasi; (2) birokrasi pada hakikatnya bersifat independen yang lepas dari intervensi luar dengan pemberlakukan sistem yang mandiri; dan (3) pelaksanaan birokrasi dipandang lebih mengakomodasi kaum partikular yang keluar dari fungsi utamanya. ${ }^{12}$ Birokrasi weberian memandang lebih dominan dalam aspek politik yang memiliki sisi menguntungkan bagi kelompok tertentu dengan mengabaikan kelompok lain yang mungkin saja mengalami kendala tertentu. Namun lebih dari itu, pelakunya sejatinya tidak langsung hadir dalam panggung politik, namun bersifat lebih netral hanya saja kebijakan yang diambil harus mengikuti peta politik yang berlaku. Oleh

10 C. Michael LeMay. Public Administration : Clashing Values in the Administration of Public Policy.(Thomson Wadsworth, 2006), hlm. 65

11 Jorgen Laegaard \& Mille Bindslev, Organizational Theory, (Ventus Publising, 2006), hlm. 17.

12 Miftah Thoha, Birokrasi \& Politik..., hlm. 19 
karena itu, kekuatan pelayanan birokrasi harus senantiasa memberikan pelayanan terbaik untuk mewadahi keseluruhan elemen yang ada.

Secara konsep, birokrasi memang memiliki keunggulan mampu mengkoordinir tugas-tugas yang banyak, dan kumpulan dari bakat-bakat tertentu. Namun, kelemahannya seorang birokrat dapat melakukan: eksekusi terhadap hukum dan aturan, dan pembuatan regulasi, adjudication (proses yang dimaksudkan untuk mengatasi ketika sebuah aturan telah dilanggar), serta lobi birokratis.

\section{Adhokrasi}

Adhokrasi (adhocracy)merupakan sebuah struktur yang rendah dalam hal kompleksitas, formalisasi dan sentralisasi. Adhocracy juga dipahami sebagai bentuk informal organisasi yang fleksibel dan adaptif yang lemah akan struktur formal. Struktur organisasi ini bersinonim dengan struktur organik,sehingga struktur ini memiliki beberapa ciri: diferensiasi horizontal tinggi, diferensiasi vertikal rendah, formalisasi rendah, desentralisasi dan fleksibilitas tinggi dan kemampuan bereaksi tinggi. ${ }^{13}$

Dikatakan diferensiasi horizontal besar, sebab struktur adhocracy memiliki banyak profesional dengan tingkat keahlian yang tinggi. Sedangkan diferensiasi vertikalnya rendah, sebab pemangkasan tingkat administrasi yang membatasi kemampuan berorganisasi yang bersangkutan dalam beradaptasi. Kebutuhan akan supervisi dalam struktur ini rendah sebab banyanyaknya profesional yang telah mamapu menginternalisasi perilaku-perilaku yang diinginkan oleh pihak manajemen. Tidak banyak aturan dalan struktur adhocracy, bahkan peraturan yang ada cenderung bersifat lepas dan tidak tertulis. Sebab fleksibilitas yang dimaksud menuntut tidak adanya formalisasi. Disamping itu, agar cepat dan dan fleksibel maka pengambilan keputusan dalam adhocracy didesentralisasi.

13 J. Winardi, Teori Organisasi dan Pengorganisasian, (Cet. 1. Jakarta: RajaGrafindo Persada, 2003), hlm. 131. 
Adhocracy memotong garis birokratik normal untuk mendapatkan kesempatan, menyelesaikan masalah dan mendapatkan hasil tertentu.

Dolan ${ }^{14}$ menjelaskan bahwa adhocracy merupakan antitesis dari segala sifat dari birokrasi. Bila birokrasi dipandang terlalu rigid terhadap akselerasi perubahan sosial dan teknologi maka segera dibutuhkan keberadaan adhocracy sebagai administratif yang normatif. Dengan demikian, dapat disimpulkan bahwa bentuk struktur adhokrasi adalah kolegial dan keputusan yang dihasilkan sebagai sebuah keseluruhan yang berkarakteristik demokrasi. Struktur ini baik diterapkan di universitas, laboratorium penelitian atau organisasi lain dengan profesionalitas yang tinggi. Tabel 1 menunjukkan ringkasan kekuatan dan kelemahan dari struktur adhokrasi.

Tabel 1. Kekuatan dan Kelemahan Adhocracy

\begin{tabular}{|c|c|c|}
\hline & Kekuatan adhocracy & Kelemahan adhocracy \\
\hline & Dapat saling berganti peranan sesuai & 1) konflik menjadi bagian yang \\
\hline & Dapat bereaksi cenat terhadap & 2) tidak terdanat hubungan vang \\
\hline & perubahan dan inovasi & jelas antara pimpinan dan \\
\hline 3) & Sebagai alternatif apabila organisasi & bawahan \\
\hline & harus adaptif dan kreatif & 3) terdapat ambiguitas otoritas dan \\
\hline 4) & Mengatasi permasalahan yang bersifat & tanggung jawab \\
\hline & $\begin{array}{l}\text { teknis, tidak terprogram, dan } \\
\text { terlampau kompleks }\end{array}$ & $\begin{array}{l}\text { 4) aktivitas-aktivitas tidak dapat } \\
\text { digolongkan }\end{array}$ \\
\hline 5) & $\begin{array}{l}\text { Pengambilan keputusan bersifat } \\
\text { kolegialitas }\end{array}$ & $\begin{array}{l}\text { 5) menimbulkan ketegangan sosial } \\
\text { dan tekanan psikologikal } \\
\text { 6) seringkali muncul kekacauan }\end{array}$ \\
\hline
\end{tabular}

Terdapat dua bentuk dari adhocracy yaitu satuan tugas (task force) dan panitia (committee). Satuan Tugas (Taskforce)adalah struktur temporal yang dibentuk untuk memenuhi tugas yang kompleks, spesifik dan terdefinisi dengan

14 Timothy E. Dolan, "Revisiting Adhocracy: From Rhetorical Revisionism to Smart Mobs", Journal od Future Studies, November 2010, 15(2). Pp. 33-50. 
jelas yang melibatkan sub-sub unit organisasi. Sebuah satuan tugas (task force) diaplikasikan ketika sebuah organisasi dihadapkan pada permasalahan yang unik, tidak umum dan membutuhkan fungsi-fungsi yang interdependen, yang berkaitan dengan kesuksesan organisasi yang memiliki waktu dan standar kinerja yang spesifik. Selain itu satuan tugas (task force) diaplikasikan untuk perubahan yang melibatkan seleksi dan instalasi peralatan modal, sistem teknologi dan proses perubahan organisasi.Satuan tugas (task force) memiliki ciri diantaranya: status anggotanya yang tidak tetap dipilih dari kualifikasi individual; lebih aktif dan cakupan tugas yang lebih luas dari panitia (committee). ${ }^{15}$ Satuan tugas (task force) sering disebut sebagai bentuk versi kecil dari matriks yang temporal.Ketika tujuan telah tercapai maka satuan tugas (task force) dapat dibubarkan. Anggota satuan tugas (task force) dapat berpindah pada satuan tugas (task force) yang baru atau kembali pada bagian atau departemen permanen-nya dalam organisasi.

Selanjutnya, panitia (committee)merupakan suatu kelompok kerja formal yang diserahi tugas untuk memecahkan suatu masalah. Panitia (committee) dapat bersifat temporal maupun permanen. Misalnya adalah panitia ujian, dan panitia penerimaan siswa baru. sedangkan yang sifatnya lebih lama misalnya dewan, komisi, majelis, dan senat.Panitia (committee) yang permanen biasanya memberikan berbagai perspektif terhadap level atas pembuat keputusan, dan memfasilitasi penyebaran informasi diantara anggota panitia (committee). Panitia (committee) secara umum memiliki ciri diantaranya: pada umumnya bertahan lebih lama; menjadi bagian tetap dari struktur organisasi formal; adanya stabilitas anggota yang dipilih; dan berperan pasif dalam identifikasi melalui saluran normal. ${ }^{16}$ Anggota sebuah panitia (committee) bertugas mengurus masalah dan keputusan, memberikan saran, menunda persetujuan, bertukar informasi secara teratur untuk mengadakan koordinasi.Baik satuan tugas (task force) maupun

15 Soenyoto Rais, Pengelolaan Organisasi, (Surabaya: Airlangga University Press, 1994), hlm. 100.

16 Soenyoto Rais, Pengelolaan..., hlm. 100. 
panitia (committee) merupakan kelompok kerja formal yang terdiri dari pada manajer dari berbagai tingkatan dan non-manajer sebagai tugas bantuan dari sebuah organisasi.

\section{Matriks}

Matriks merupakan salah satu struktur organisasi yang muncul setelah era birokrasi atau yang disebut sebagai era post-bureaucratical organization. Dalam bentuk organisasi matriks digambarkan koordinasi antar departemen atau bidang atau bagian yang ada di dalam organisasi. Bentuk organisasi matriks merupakan pendekatan yang yang dilahirkan untuk clean up pendekatan-pendekatan yang sebelumnya yang tidak memberi kemudahan serta fleksibilitas dalam menangani kegiatan-kegiatan yang kompleks dan melibatkan keahlian atau skill dari berbagai bidang fungsional organisasi. Menurut Stoner, organisasi matriks adalah sebuah struktur keorganisasian, dimana masing-masing karyawan bertanggung jawab kepada seorang manajer fungsional atau manajer divisi dan terhadap manajer proyek atau manajer kelompok. ${ }^{17}$ Organisasi matriks meliputi cara-cara penggabungan manajer-manajer organisasi dengan berbagai spesialisasi untuk menyelesaikan suatu tugas.

Pada organisasi matriks, para karyawan pada dasarnya memiliki dua orang pemimpin. Mereka berada dibawah dua kepemimpinan (under dual authority). Struktur organisasinya terbagi dalam beberapa divisi dibawah direktur utama. Setiap divisi memiliki wewenang dan tanggung jawab tersendiri. Dengan adanya pembagian divisi tersebut tugas dan pekerjaan menjadi lebih mudah dan lebih fleksibel, mendorong adanya kerja sama antar divisi. Adanya pembagian divisidivisi tersebut maka setiap bagian harus menjaga koordinasi dan komunikasi yang baik agar tidak terjadi konflik horisontal maupun vertikal yang diakibatkan adanya kesalahan tanggung jawab ganda. Gambar 1 menunjukkan bentuk organisasi matriks.

17 J. Winardi, Teori..., hlm. 109. 


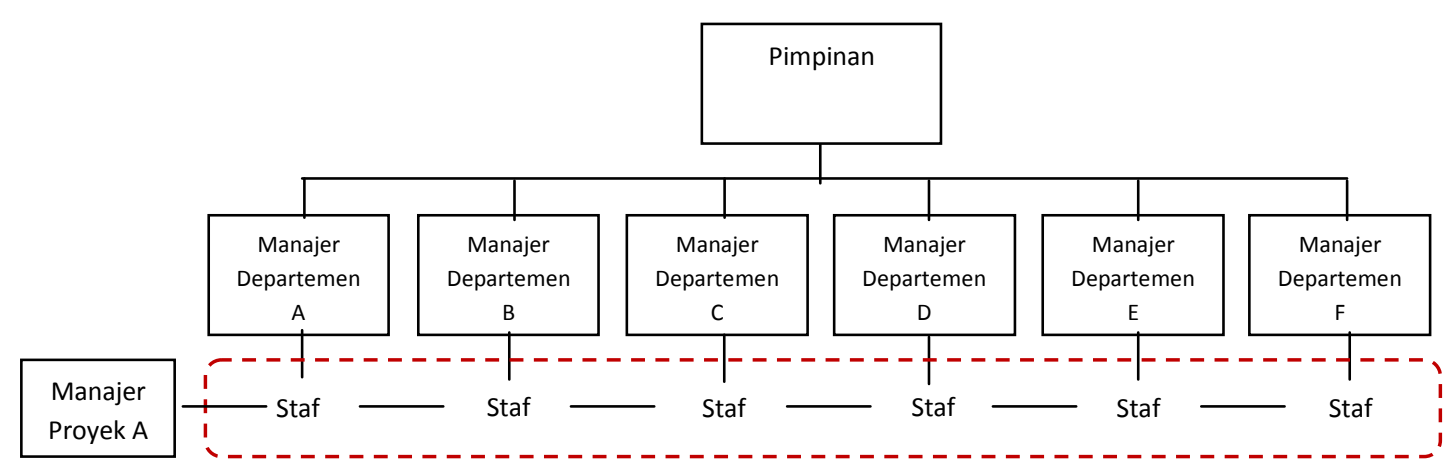

Gambar 1. Bentuk organisasi matriks

Konsep organisasi matriks berkembang dan banyak diadopsi pada organisasi-organisasiyang bekerja dengan banyak proyekdi dalamnya yang memerlukan koordinasi dan prestasi teknis yang tinggi, serta membutuhkan berbagai keterampilan dan keahlian khusus.Diantaranya ditemui pada agen-agen periklanan, laboratorium penelitian dan pengembangan, perusahaan konstruksi, lembaga pemerintah, universitas dan rumah sakit. Tabel 2 merupakan kelebihan dan kelemahan dari bentuk matriks: ${ }^{18}$

Tabel 2. Kelebihan dan Kelemahan Matriks

\begin{tabular}{|c|c|}
\hline Kelebihan Matriks & Kelemahan Matriks \\
\hline $\begin{array}{l}\text { 1) Memaksimalkan efesiensi penggunaan } \\
\text { tenaga-tenaga fungsional dan } \\
\text { struktural. } \\
\text { 2) Memberikan fleksibilitas kepada } \\
\text { organisasi dan membantu } \\
\text { perkembangan kreativitas serta } \\
\text { pelipatgandaan pemanfaatan sumber- } \\
\text { sumber yang beraneka ragam. }\end{array}$ & $\begin{array}{l}\text { 1) Adanya pertanggung jawaban } \\
\text { ganda dapat menciptakan } \\
\text { kebingungan dan kebijakan- } \\
\text { kebijakan yang kontradiktif. } \\
\text { 2) Sangat dibutuhkan koordinasi } \\
\text { horisontal dan vertikal } \\
\text { 3) Dibutuhkan lebih banyak } \\
\text { keterampilan-keterampilan }\end{array}$ \\
\hline
\end{tabular}

${ }^{18}$ Dydiet Hardjito, Teori Organisasi..., hlm. 39; J. Winardi, Teori ..., hlm. 112 


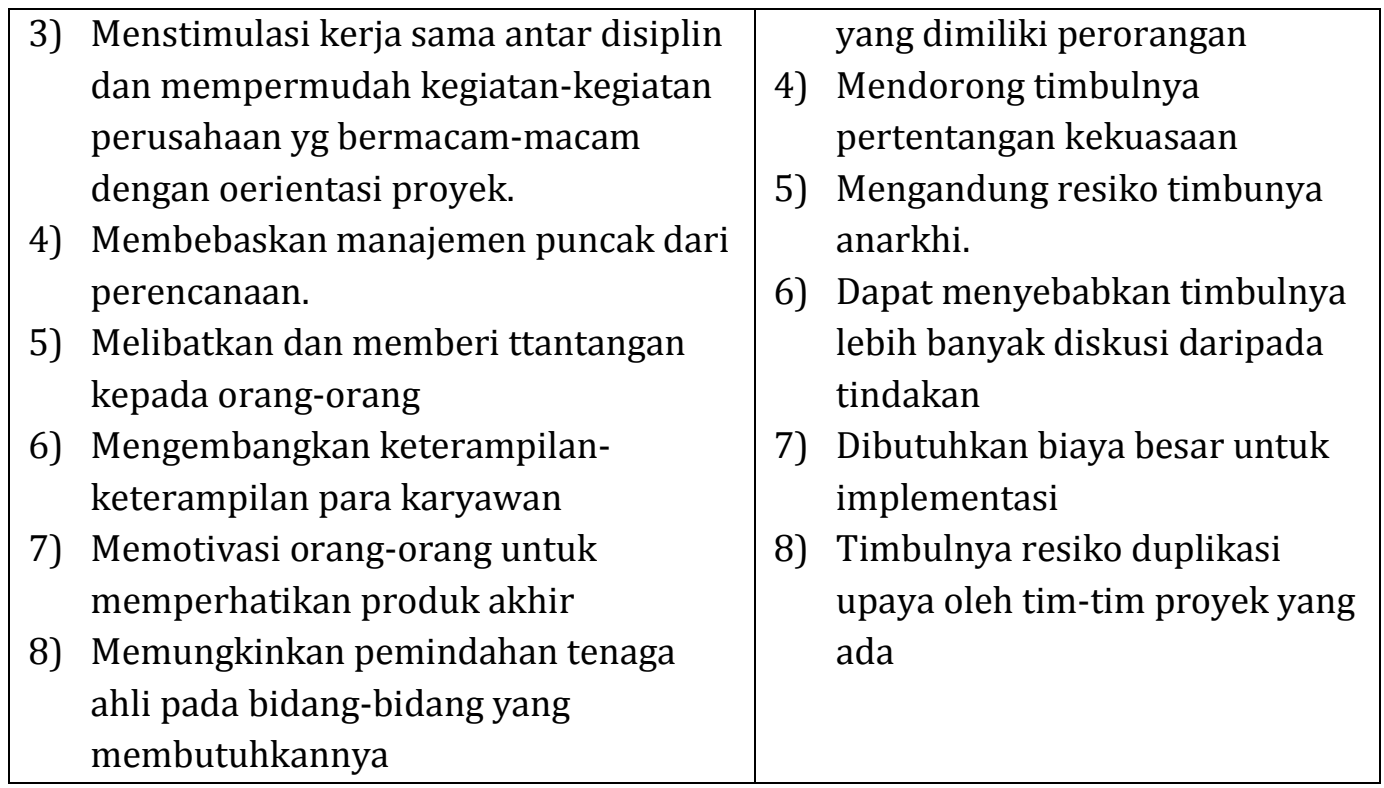

Matriks mencoba memecah penghalang-penghalang dengan mengijinkan para karyawan dari departemen atau unit atau bagian yang berbeda fungsi dan menyatukan keahlian yang dimiliki untuk memecahkan masalah bersama. Organisasi matriks meningkatkan kemampuan organisasi dalam memanfaatkan sumber daya manusia secara bijak dan dapat menyesuaikan diri dengan perubahan lingkungan yang ada.

\section{Berbagai Kritik atas Birokrasi}

Menurut Widaningrum, ${ }^{19}$ sistem administrasi dan manajemen dalam birokrasi memang tidak didisain untuk sering berubah. Namun demikian, kenyataannya menunjukkan bahwa stabilitas seringkali bersifat sebaliknya (counter-productive). Dalam era yang penuh dengan perubahan seperti sekarang ini, sistem yang tidak dapat berubah justru akan menemui banyak kegagalan. Kegagalan ini dibuktikan dengan berbagai kajian empiris yang membuat

19 Ambar Widaningrum. Reformasi Manajemen Pelayanan Kesehatan, dalam Pramusinto dan Purwanto (ed). Reformasi Birokrasi, Kepemimpinan, dan Pelayanan Publik: Kajian tentang pelaksanaan otonomi daerah di Indonesia. (Yogyakarta; Gaya Media. 2009), hlm. 368 
menunjukkan bahwa birokrasi justru melahirkan berbagai problematika di berbagai negara.

Okotoni, ${ }^{20}$ dalam menganalisis permasalahan dan prospek birokrasi di Nigeria menemukan bahwa bahwa birokrasi publik di Nigeria yang telah dipengaruhi adanya warisan kolonial, pemerintahan militer yang berkepanjangan, lingkungan politik yang tidak stabil, krisis ekonomi, ancaman sosial, penyimpangan Konstitusi, kebijakan publik yang tidak menguntungkan, hambatan birokrasi (seperti kekakuan, sentralisasi, lapisan birokrasi yang berlebihan), kondisi Layanan yang buruk dll. Semua faktor ini telah menghambat kinerja yang efektif birokrasi Nigeria dalam beberapa cara.

William Easterly ${ }^{21}$ dalam mengeksplorasi permasalahan birokrasi di badan bantuan luar negeri, mendapati bahwa Birokrasi tidak bekerja baik di badan bantuan luar negeri. Birokrasi yang berjalan di badan bantuan luar negeri tersebut menjadi (a) lebih cenderung mendefinisikan output mereka dalam bentuk uang daripada berupa penyampaian layanan (b) menghasilkan output yang rendah pengamatan dan rendah evaluasi (c) terikat dalam kontrol perputaran dan amnesia (senantiasan menghasilkan usaha yang baru dan dikembangkan) sehingga sedikit dapat belajar dari masa lalu (d) memunculkan permintaan besar adanya keahlian administratif yang langka ada di negara miskin.

Ochrana, Plaek, \& Pucek, ${ }^{22}$ dalam mengevaluasi penyebab inefisiesi birokrasi di Republik Ceko, menemukan bahwa problematika rendahnya efisiensi birokrasi di Ceko tidak disebabkan karena input (karena tingkat pendidikan yang rendah dan karena usia mereka yang sudah tua), tetapi dapat dilihat lebih karena internal organisasi pemerintah, dalam cara manajemen birokrasi yang cenderung

${ }^{20}$ Olu Okotoni. "Problems and Prospects of Nigerian Bureaucracy." Journal of Social Sciences 7.3 (2001): 223-229.

${ }^{21}$ William Easterly. "The cartel of good intentions: the problem of bureaucracy in foreign aid." The Journal of Policy Reform 5.4 (2002): 223-250.

${ }^{22}$ František Ochrana,, Michal Plaček, and Milan Půček. "Reasons for the Infectiveness of the Czech State Bureaucracy: Myths and Reality." Procedia Economics and Finance 30 (2015): 622-630. 
melanggengkan "kelangsungan" cara para pejabat Menteri bekerja dari tahun-tahun sebelumnya dan juga mungkin karena jumlah pejabat yang terlalu"berlebihan" di struktur organisasi pemerintahan. Poocharoen, ${ }^{23}$ dalam menganalisis permasalahanyang berhubungan dengan struktur birokrasi di Thailand bagian selatan, mendapati bahwa Birokrasi terbukti tidak mampu dikembangkan dengan baik dalam lingkungan yang tidak stabil di Thailand selatan. Bahkan sistem training, reward dan hukuman tidak efektif dalam menjawab realitas perubahan yang terjadi.

Penggunaan birokrasi yang buruk di Iran, ditemukan oleh Javadian \&Addae, ${ }^{24}$ telah menyebabkan rendahnya partisipasi perempuan Iran di organisasi publik. Di Indonesia, Nurkholis ${ }^{25}$ dalam memotret birokrasi pendidikan, mendapati bahwa para penyedia layanan pendidikan banyak sekali sikap apatis, menolak berurusan, sikap dingin, memandang rencah masyarakat, para pegawai pendidikan bekerja secara mekanis dan taat prosedur. Padalah pendidikan sejatinya dikelola oleh para kaum profesional dengan semangat kolegialitas yang memberikan kemudahan pada setiap pihak untuk dapat secara bersama melahirkan generasi-generasi berkarakter dan berprestasi

Berbagai temuan empiris problematika birokrasi di berbagai negara di atas, pada dasarnya menegaskan bahwa birokrasi sangat lemah untuk tetap digunakan saat ini karena melahirkan apa yang disebut Caiden ${ }^{26}$ sebagai patologi birokrasi. Jika birokrasi melahirkan banyak patologi, maka bagaimana birokrasi dapat tetap digunakan di era globalisasi yang penuh dengan tuntutan perubahan saat ini? kebutuhan untuk tetap survive dan jaya dengan keterbatasan sumber

230ra-Orn Poocharoen. "The Bureaucracy: Problem or Solution to Thailand's Far South Flames?."Contemporary Southeast Asia: A Journal of International and Strategic Affairs 32.2 (2010): 184-207.

${ }^{24}$ Golshan Javadian and Isaac Y. Addae. "The impact of bureaucracies and occupational segregation on participation of Iranian women in the workforce." Equality, Diversity and Inclusion: An International Journal 32.7 (2013): 654-670. 55

${ }^{25}$ Nurkolis. "Potret Birokrasi pendidikan di Indonesia", JMP, Vol. 2, No. 1 (2015): 44-

${ }^{26}$ Gerald E Caiden. "What really is...", pp: 486-493 
daya manusia dan pendanaan dalam pasar yang kompetitif tentu memaksa setiap organisasi untuk menyediakan prosedur standar yang inovatif, fleksibel dan menyeluruh.

\section{Tantangan Birokrasi pada Institusi Pendidikan}

Institusi pendidikan yang pada dasarnya merupakan birokrasi profesional, ditengah persaingan global ini semakin dituntut untuk lebih inovatif dalam upaya menjaga keberlangsungan hidupnya. Para akademisi biasanya, melakukan pekerjaannya dalam struktur birokrasi yang rigid, dengan serangkaian aturan administratif baku yang harus mereka jalani. Dalam artian mereka sering kehilangan hak otonomi mereka. Karakteristik dari birokrasi dalam lingkungan pendidikan, biasanya adalah sebagai berikut:

1. Pembagian staf. Organisasi pendidikan dan sekolah dipisahkan tingkatannya berdasar usia dan spesialisasi pekerjaanya. Berkembangnya layanan spesialis dan bidang-bidang dengan keahlian khusus. Adanya pembedaan manajer atau kader administratif

2. Adanya hirarki. Adanya pembedaan level kekuasaan dan wewenang dalam organisasi yang ditentukan bidang-bidang dengan keahlian khusus. Supervisi dimaksudkan untuk memastikan terwujudnya praktik, nilai dan tujuan organisasi.

3. Peraturan formal yang eksplisit. Praktik dibentuk seragam melalui aturan yang eksplisit dan panduan bertingkakh laku individu dan untuk menyelesaikan tugas, misal adanya SOP. Melaului peraturan yang eksplisit didefinisikan cara melakukan satu untuk membentuk definisi diri, dan identitas grup seta interaksi.

4. Spesialisasi dijamin melalui pelatihan. Pengetahuan teknis yang terbukti secara ilmiah sebagai dasar untuk praktek profesional. Pelatihan atau 
internalisasi dan penguasaan pengetahuan dasar merupakan syarat mutlak akan kesuksesan dan kemajuan organisasi.

5. Dokumentasi tertulis. Catatan sistematis tetap dilakukan sebagai aktivitas organisasi yang dimaksudkan untuk memastikan bahwa kinerja profesional dan pencapaian individu secara efektif dipantau dan dikelola. Masing-masing anggota organisasi menuliskansejarahnya sendiri akan pencapaian dan kegagalan.

6. Cita-cita dan standar yang eksplisit. Cita-cita atau tujuan eksplisit memberi perintah, berorientasi dan harmonisasi pada proyek organisasi dan pada kerja individu. Standar eksplisit memastikan kejujuran dalam bekerja dan evaluasi manajerial.

Meski telah lama digunakan disektor pendidikan, berbagai kritik dan serangkaian kajian empiris, membuktikan bahwa birokrasi kurang kompatibel digunakan dalam organisasi pendidikan. Seperti kajian Bohte ${ }^{27}$ mendapati bahwa birokrasi memiliki pengaruh negatif terhadap kinerja administratif pegawai serta kinerja siswa. Mehta ${ }^{28}$ secara tegas mengatakan bahwa berbagai permasalahan yang dihadapi sekolah di Amerika merupakan hasil birokrasi yang secara keseluruhan telah menyusun sektor pendidikan. Meski telah berusaha direformasi, Benneth ${ }^{29}$ menunjukkan bahwa reformasi birokrasi di Kanada justru cenderung mengarah pada trend bentuk baru sentralisasi administratif tanpa memperhatikan akuntabilitas atau atensi publik terhadap hasil kinerja siswa. Berbagai persoalan yang muncul akibat birokrasi di lingkungan pendidikan, seolah telah mendorong Howard ${ }^{30}$ untuk menyerukan bahwa sekolah yang suskes harusnya dilepaskan dari

27John Bohte. "School bureaucracy and student performance at the local level." Public Administration Review 61.1 (2001): 92-99.

${ }^{28} \mathrm{Jal}$ Mehta. "From Bureaucracy to Profession: Remaking the Educational Sector for the Twenty-First Century." Harvard Educational Review 83.3 (2013): 463-488.

29 Paul W. Bennett, "Consolidation, Bureaucracy and The Public Schools: The Formation of The Modern Bureaucratic Education State, 1920 To 1993", Canadian Issues Spring (2014): 16-22

30Philip K. Howard (2012). "To Fix America's Education Bureaucracy, We Need to Destroy It". The Atlantic. 
birokrasi dan membiarkan inspirasi dan harapan individu berkembang. Haruskah birokrasi dihilangkan dari sistem pendidikan?

Bagaimanapun perlu juga disadari bahwa globalisasi dan kemajuan teknologi yang begitu cepat di era informasi telah menyebabkan lingkungan organisasi pendidikan saat ini menjadi semakin kompleks. Dalam konteks ini, pengelolaan pendidikan menjadi lebih ditantang untuk bisa menghadirkan manajemen organisasi yang efektif, yang mampu dengan fleksibel menghadapi tuntutan globalisasi. Xi dan Zhang ${ }^{31}$ menyebutkan bahwa lingkungan organisasi kontemporer dikarakteristikan oleh empat komponen kunci yang terdiri dari complexity, change, ambiguity, and uncertainty(CCAU). Pertama, complexity (kompleksitas), memiliki makna kerumitan atau keruwetan. Yaitu, menunjukkan adanya suatu keadaan yang rumit, dimana satu peristiwa menjadi satu kesatuan dengan peristiwa-peristiwa lain yang saling tergantung satu sama lain. Hal ini disebabkan kemajuan teknologi informasi, yang telah membuat jarak fisik tidak menjadi persoalan.Kedua, change (perubahan), bermakna menjadi berbeda dengan sebelumnya atau berganti dengan yang lain.

Dengan perkembangan ekonomi pasar yang cenderung mengarah pada dominasi neoliberal, maka persaingan antara lembaga pendidikan memiliki menjadi tidak terelakkan. Ketiga, uncertainity atau ketidakpastian berasal dari kata tidak pasti yang dapat bermakna tidak tentu, atau tidak tetap. Dalam konteks organisasi pendidikan, ketidaktentuan merupakan fenomena yang dialami oleh para manajer dan pengambil keputusan karena kurangnya informasi yang dimiliki. Kondisi masa depan misalnya, merupakan ketidakpastian yang menyebabkan sebuah organisasi pendidikan harus terus mampu berinovasi agar mampu bertahan di masa yang semakin sulit ini. Keempat, ambiguity (ambiguitas) berasal dari kata ambigu yang bermakna lebih dr satu, sehingga kadang-kadang

31 Youmin Xi and Xiaojun Zhang, "Replying to management Challenges: Integrating oriental and occidental wisdom by HeXie Management Theory", Chinese Management Studies, Vol. 6 (3), 2012, pp. 395-412. Emerald Group Publishing Limited 
menimbulkan keraguan, kekaburan, dan ketidakjelasan. Dalam konteks organisasi pendidikan, ambiguitas mengacu pada kurangnya kesadaran organisasi atas lingkungan mereka saat ini, di mana manajer memiliki pengetahuan yang kurang memadai tentang makna dan implikasi dari peristiwa tertentu, atau kurang memahami hubungan sebab akibat dari sebuah peristiwa. Misalkan, apakah untuk memahami apakah rendahnya prestasi siswa disebabkan karena kurikulumnya, gurunya, siswanya sendiri atau fasilitasnya atau yang lainnya?

Dalam konteks tantangan lingkungan CCAU, maka salah satu problematika yang dihadapi manajemen sebuah organisasi pendidikan di era globalisasi saat ini adalah problematika pengelolaan organisasi pendidikan secara holistik. Dalam kondisi adanya kompleksitas, perubahan, ambiguitas dan ketidakpastian lingkungan saat ini, dibutuhkan komunikasi yang efektif serta koordinasi antar departemen yang berbeda yang berbeda. Dan ini menjadi sangat penting bagi keberhasilan organisasi secara keseluruhan. Manajemen tradisional yang umumnya menganut karakteristik birokrasi seringkali mendasarkan pada pemisahan fungsional, dengan pembagian tugas yang kaku dan prosedural, tentu kurang mampu menghadapi masalah pengelolaan secara holistik. Akibatnya, jika sebuah institusi pendidikan harus menghadapi problematika yang berkaitan dengan perubahan lingkungan dan ketidakpastian, akan sulit jika birokrasi tetap digunakan.

\section{E. Mengintegrasikan Adhokrasi dan Manajemen Matriks dalam Struktur Organisasi Birokrasi pada Institusi Pendidikan}

Pelaksanaan institusi pendidikan yang baik akan berdampak pada pelayanan pendidikan yang dihasilkan dengan proses interaksi yang efektif dan efisien. Dalam pada itu, pimpinan harus membuat aturan yang tegas dengan pertimbangan yang mapan untuk efektifitas dan tercapainya mutu pendidikan yang dihasilkan. 
Untuk menjawab problematika yang dihadapi atas kakunya birokrasi dihadapkan dengan problematika lingkungan kontemporer, maka artikel menghadirkan solusi untuk mengintegrasikan adhokrasi dan matriks dalam stuktur birokrasi pada institusi pendidikan, sebagaimana digambarkan pada gambar 2.

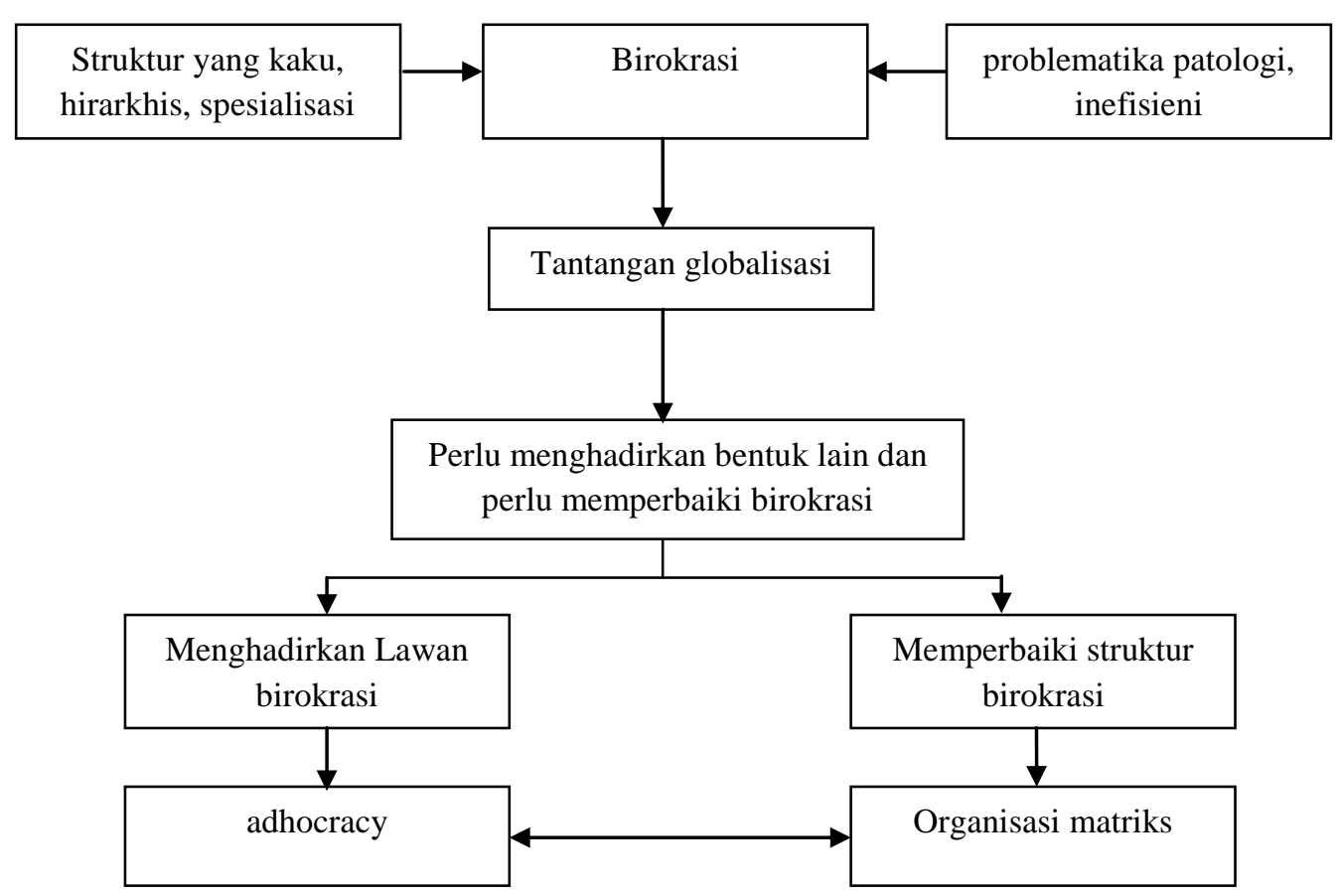

Gambar 2. Solusi Integrasi adhokrasi dan matriks dalam birokrasi insitusi pendidikan

Birokrasi masihlah diperlukan di lingkungan pendidikan khususnya dalam konteks pendidikan nasional (penyelenggaraan pendidikan dalam organisasi negara), sehingga tidak perlu dihapus atau dihilangkan sama sekali. Kritik-kritik terhadap birokrasi tersebut memang telah menunjukkan ketegasan bahwa mereka 
memiliki keterbatasan yang cukup serius. Namun Bush ${ }^{32}$ mengingatkan bahwa meski terdapat keterbatasan, akan menjadi tidak tepat jika mengabaikan pendekatan formal (birokrasi) sebagai pendekatan yang relevan untuk sekolah dan perguruan tinggi. Faktanya, meskipun model-model lain telah dikembangkan sebagai reaksi yang dirasakan atas kelemahan dari birokrasi, perspektif alternatif ini belum berhasil mencabut keberadaan model formal (sebagai salah satu bentuk birokrasi), yang tetap berlaku sebagai deskripsi parsial dari organisasi dan manajemen pendidikan. Owens dan Shakeshaft 33 merujuk pada adanya penurunan kepercayaan dalam model birokrasi, menegaskan bahwa model formal birokrasi masih tetap memiliki banyak kontribusi terhadap pemahaman tentang sekolah sebagai organisasi.

Pemahaman tentang jenis struktur organisasi yang bervariatif akan ditemukan bahwa di dalamnya ada dua struktur yaitu mekanik dan organik. Struktur organisasi mekanik disusun dengan mempertimbangkan kerja yang stabil dengan memaksimalkan tugas pokok dan fungsi secara efektif dan efisien dengan memperhatikan posisi yang diembang oleh seseorang. Tugas tersebut diberikan berdasarkan otoritas dan kecukupan informasi yang harus dijunjung tinggi dan tidak boleh dilanggar dengan proses dan promosi yang benar agar terjadi keselamatan organisasi tersebut. Struktur organisasi organik berjalan sebaliknya dimana proses adaptasi harus dilakukan terlebih dahulu dengan adanya proses belajar dalam durasi waktu tertentu. Upaya ini diharapkan adanya sikap yang familiar dengan lingkungannya, namun struktur ini terkadang tidak efektif jika ditemukan adanya kurang cakapnya dalam menjalankan tugas dengan durasi waktu yang diberikan, begitu juga untuk lingkungan yang cenderung berubah-

${ }^{32}$ Bush, Tony. "Theories of Educational Management." International Journal of Educational Leadership Preparation 1.2 (2006): n2

${ }^{33} \mathrm{R}$. Owens, and C. Shakeshaft. "The new revolution in administrative theory", Journal of Educational Management, 30: 9, (1992): 4-17. 
ubah dan sifat permasalahannya tidak dapat diatasi dengan cara-cara rutin, organisasi organik akan lebih mendukung. ${ }^{34}$

Merujuk pada dua konsep mekanik dan organic ini, maka dapat disimpulkan bahwa birokrasi cenderung mekanistik. Hal inilah yang menyebabkan organisasi pendidikan (secara khusus adalah unit pendidikan) yang menggunakan birokrasi menjadi kurang fleksibel dalam mengambil keputusan dan mengelola organisasi secara holistik. Berbagai persoalan yang membutuhkan penganganpenangan khusus seperti penurunan jumlah pendaftar, keinginan untuk menjadi berkelas internasional, pengintegrasian ICT dan sebagainya, akan sulit terwujud mengingat struktur piramida dalam birokrasi telah menyebabkan terhambatnya pengambilan keputusan cepat dan efektif karena harus selalu menunggu atasan dan taat prosedur. Organisasi pendidikan yang terdiri dari kaum profesional membutuhkan organisasi yang fleksibel, yang lebih organic jika menghadapi kebutuhan khusus. Dalam hal ini solusinya adalah menghadirkan sebuah struktur organik dalam organisasi. Maka,adhocracy dapat menjadi jawabannya.

Adhocracy yang dihadirkan Mitzberg sebagai lawan dari birokrasi, yang berusaha menghilangkan kekakuan, hirarkhi dan spesialisasi dari birokrasi dapat menjadi solusi ketika organisasi harus berhadapan dengan tantangan dan kebutuhan tertentu. Beberapa kajian empiris telah menunjukkan bahwa adhocracy dapat menjadi solusi di beberapa institusi yang memiliki banyak kaum profesional. Misalnya, Unger et al.,35 dengan menggunakan konsep struktur organisasi Mintzberg mendapati bahwa Adhocracy sebagai sebuah konfigurasi yang cocok bagi organisasi kesehatan yang membutuhkan tingkat otonomi, partisipasi komunitas, inisiatif staf medis, dan evaluasi berkelanjutan, yang tinggi. Haffar, Al73-74

${ }^{34}$ Kusdi. Teori Organisasi dan Administrasi. (Jakarta: Salemba Humanika, 2009), hlm.

35Jean-Pierre Unger, et al. "Through Mintzberg s glasses: a fresh look at the organization of ministries of health." Bulletin of the World Health Organization78.8 (2000): 1005-1014. 
Karaghouli dan Ghoneim, ${ }^{36}$ dalam menguji pengaruh empat tipe budaya (group, market, hierarchy dan adhocracy) terhadap kesiapan individu atas perubahan, mendapati bahwa adhocracy merupakan tipe budaya yang paling suportif dalam mendukung kesiapan individu atas perubahan.

Dalam konteks satuan pendidikan, adhocracy sebagai lawan dari birokrasi, akan memberikan kesempatan para akademisi profesional di lingkungan lembaga pendidikan untuk mengatasi persoalan yang dihadapi institusi. Dengan berisi kalangan profesional, tanpa banyak aturan dalan struktur, bahkan peraturan yang ada cenderung bersifat lepas dan tidak tertulis, dan fleksibilitas yang menuntut tidak adanya formalisasi, maka setiap anggota akan memiliki kebebasan untuk dapat berpartisipasi dengan cepat memecahkan persoalan yang dihadapi oleh institusi.

Namun, untuk dapat berjalan dengan baik, struktur organisasi harus menghadirkan desentralisasi pada setiap bagian, sehingga pengambilan keputusan dapat dibuat secara lebih cepat dan mudah, yaitu mengubah manajemen menjadi bersifat matriks. Dengan kata lain, agar tidak terlalu kaku, birokrasi perlu mendapatkan sentuhan dari struktur birokrasi kontemporer dari masa post birokrasi, berupa manajemen matriks. Dalam dunia pendidikan adopsi terhadap struktur organisasi matriks disebabkan makin meluasnya produk pendidikan dan makin banyak dan kompleksitas sebuah organisasi pendidikan, khususnya universitas. Dengan diintegrasikannya adhocracy dan struktur organisasi matriks, hal ini akan memudahkan penempatan proyek-proyek yang digagas atau dibutuhkan oleh institusi dalam struktur dengan pembagian kewenangan yang jelas, dengan tetap memberikan keleluasaan pada masing-masing anggota divisi. Gambar 3 menunjukkan gambaran sederhana bagaimana adhocracy dapat

${ }^{36}$ Mohamed Haffar, Wafi Al-Karaghouli, and Ahmad Ghoneim. "An empirical investigation of the influence of organizational culture on individual readiness for change in Syrian manufacturing organizations."Journal of Organizational Change Management 27.1 (2014): 5-22. 
dimasukkan dalam manajemen matriks di sebuah institusi pendidikan, dalam sebuah proyek World Class University (WCU).

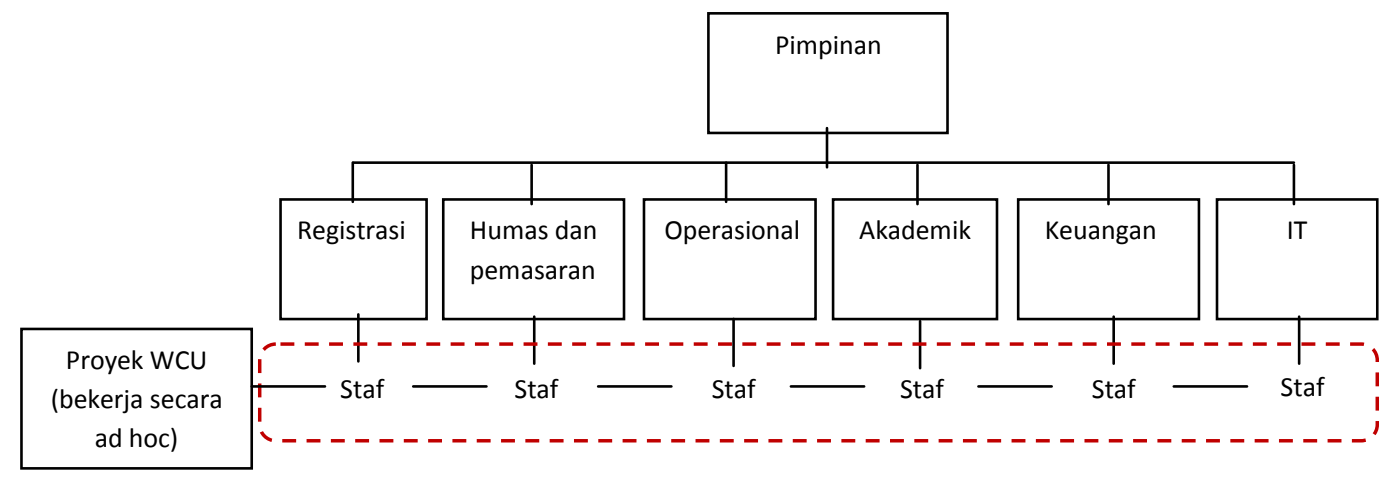

Gambar 3. Pengintegrasian adhocracy dan struktur organisasi matriks dalam proyek WCU di lembaga pendidikan

Birokrasi dengan bentuknya yang formal dan rasional meski sekarang ini masih mewarnai pengelolaan organisasi pendidikan. Akan tetapi, dibutuhkan pendekatan lain yang lebih bersifat fleksibel dan efisien dalam menghadapi perubahan. Masuknya pada era globalisasi dengan tingkat persaingan yang ketat serta perubahan terjadi begitu cepat maka organisasi harus memiliki stuktur yang lebih fleksibel dan adaptif. Reformasi birokrasi dalam skala unit pendidikan dirasa belum mampu membuat perubahan yang signifikan. Makin berkembangnya unit pendidikan membutuhkan stuktur yang mampu mengatasi segala bidang baru yang mungkin muncul serta berbagai proyek-proyek demi pengembangan unit pendidikan. Di samping itu, juga dibutuhkan pendekatan yang dapat mengoptimalkan karakteristik unit pendidikan yang berisi para profesional dengan tingkat keahlian, inovasi dan kreatifitas yang tinggi. Maka bentuk organisasi yang matrik dengan dual authority serta pendekatan yang lebih bersifat 
adhoc diharapkan mampu menjawab tantangan-tantangan yang dihadapi masingmasing unit pendidikan ke depannya.

Meski adopsi struktur matriks pada unit pendidikan dapat dijadikan alternatif pengelolaan organisasi pendidikan masa mendatang, namun bukannya tanpa kelemahan dan tantangan. Struktur tersebut diperuntukkan bagi organisasi dengan komplesitas yang tinggi (bidang-bidang variatif) sehingga menjadi cocok bagi organisasi universitas. Sedangkan bagi unit pendidikan dengan skala yang lebih kecil seperti sekolah menjadi permasalahan tersendiri. Secara umum sekarang ini sekolah-sekolah masih berstruktur birokrasi-fungsional. Di sisi lain, karakterteristik adhocracymemang sesuai dengan stuktur organisasi pendidikan yang berisi para profesional dengan tingkat keahlian, inovasi dan kreatifitas yang tinggi. Akan tetapi, sifat mendasar dari struktur ini adalah bersifat temporal. Hal ini dapatmemunculkan permasalahan ketika dalam sebuah struktur adhocracy adalah relationship system yang ada,terdapat perbedaan posisi atau jabatan yang mampu memberikan noise dalamrelationship system sehingga optimalisasi belum dapat terwujud.

\section{F. Kesimpulan}

Birokrasi sebagai struktur yang diperkenalkan Max Weber untuk mendongkrak sistem organisasi agar memberikan sistem manajemen yang adil dengan mengurangi kecenderungan manusia dalam membuang waktu, dan praktik diskriminasi, justru semakin hari, kian memunculkan banyak kritik. Bahkan kini, birokrasi lebih dikenal sebagai struktur dengan urusan berbelit-belit, prosedur yang panjang dan memakan waktu, penuh KKN, serta struktur yang terlalu besar. Pada sektor pendidikan, struktur birokrasi telah diadopsi dan digunakan sangat lama sebagai struktur administratif universal dalam menjalankan manajemen lembaga pendidikan sehari-hari, di berbagai penjuru dunia. meski demikian, tetap saja melahirkan kritik atas penggunaan birokrasi yang melahirkan praktik diskriminasi dan ketidakadilan sistemik 
Untuk mengatasi persoalan kritik birokrasi, yang perlu diupayakan bukanlah menghapus dan mengganti birokrasi, namun mengintegrasikan berbagai bentuk struktur baru yang berkembang. Bagaimanapun, birokrasi masih dibutuhkan untuk menempatkan kekuasaan (powering) sebagaialat dalam menjalankan organisasi. Untuk memberikan keleluasaan kepada para kaum profesional dalam memecahkan masalah serta memunculkan kreativitas dan inovasi masing-masing, maka adhokrasi dapat diintegrasikan dengan sekaligus menggabungkan bentuk manajemen matriks yang dibutuhkan untuk memberikan kewenangan melalui persuasi dan dialog atau pemberdayaan (empowering).Dengan demikian terjadi kombinasi antara hirarkhi dengan desentralisasi (pembagian kewenangan).

\section{Daftar Rujukan}

Beetham, D. Bureaucracy. U of Minnesota Press. 1996

Bennett, Paul W. "Consolidation, Bureaucracy and The Public Schools: The Formation of The Modern Bureaucratic Education State, 1920 To 1993", Canadian Issues - Spring. 2014. pp: 16-22

Blau, P. M. Bureaucracy in modern society. Crown Publishing Group/Random House. 1956

Bohte, John. "School bureaucracy and student performance at the local level." Public Administration Review61(1) 2001. pp: 92-99. https://doi.org/10.1111/0033-3352.00008

Bush, T. Theories of Educational Management. International Journal of Educational Leadership Preparation. 1(2) 2006.

Caiden, G. E. What really is public maladministration?. Public Administration Review. $\quad 1991 . \quad$ p. $\quad 486-493$. https://doi.org/10.1177\%2F0019556119910101

Dolan, Timothy E. "Revisiting Adhocracy: From Rhetorical Revisionism to Smart Mobs", Journal od Future Studies, 15(2) 2010. Pp. 33-50. 
Easterly, William. "The cartel of good intentions: the problem of bureaucracy in foreign aid." The Journal of Policy Reform 5(4) 2002. pp: 223-250.

Haffar, Mohamed, Wafi Al-Karaghouli, and Ahmad Ghoneim. "An empirical investigation of the influence of organizational culture on individual readiness for change in Syrian manufacturing organizations."Journal of Organizational Change Management, Vol.27(1) 2014. pp: 5-22. https://doi.org/10.1108/JOCM-04-2012-0046

Hardjito, Dydit. Teori Organisasi dan Teknik Pengorganisasian. Jakarta: Raja Grafindo Persada. 1995. Cet. III

Hardjito, Dydit. Teori Organisasi dan Teknik Pengorganisasian. Jakarta: Raja Grafindo Persada. 1995. Cet. III

Howard, Philip K. "To Fix America's Education Bureaucracy, We Need to Destroy It". The Atlantic. 2012. https://www.theatlantic.com/national/archive/2012/04/to-fix-americaseducation-bureaucracy-we-need-to-destroy-it/255173/

Javadian, Golshan and Isaac Y. Addae. "The impact of bureaucracies and occupational segregation on participation of Iranian women in the workforce." Equality, Diversity and Inclusion: An International Journal 32(7) 2013. pp: 654-670. https://doi.org/ 10.1108/EDI-08-2012-0067

Jull, Stephen. K. Locating gender bias and systemic discrimination in public schooling bureaucracy.Alberta journal of educational research, 48(1) 2002

Kusdi. Teori Organisasi dan Administrasi. Jakarta: Salemba Humanika. 2009

Laegaard, Jorgen \& Mille Bindslev. Organizational Theory. Ventus Publising. 2006

LeMay, C. Michael. Public Administration : Clashing Values in the Administration of Public Policy. Thomson Wadsworth. 2006

Mehta, Jal. "From Bureaucracy to Profession: Remaking the Educational Sector for the Twenty-First Century." Harvard Educational Review 83(3) 2013. pp: 463-488. https://doi.org/10.17763/haer.83.3.kr08797621362v05 
Mintzberg, Henry. "Structure in 5's: A Synthesis of the Research on Organization Design." Management science $26 \quad$ (3) $1980 \quad$ pp: 322-341. https://doi.org/10.1287/mnsc.26.3.322

Nurkolis. "Potret Birokrasi pendidikan di Indonesia”, JMP Vol. 2 (1) 2015, hlm: 4455.

Ochrana, František, Michal Plaček, and Milan Půček. "Reasons for the Infectiveness of the Czech State Bureaucracy: Myths and Reality." Procedia Economics and Finance 30. 2015. pp: 622-630. https://doi.org/10.1016/S22125671(15)01275-7

Okotoni, Olu. "Problems and Prospects of Nigerian Bureaucracy." Journal of Social Sciences $7(3) \quad 2001 . \quad$ pp: 223-229. https://doi.org/10.1080/09718923.2003.11892384

Owens, R. and C. Shakeshaft. "The new revolution in administrative theory", Journal of Educational Management, 30 (9) 1992. pp: 4-17. https://doi.org/10.1108/09578239210014432

Rais, Soenyoto. Pengelolaan Organisasi. Surabaya: Airlangga University Press. 1994 Thoha, Miftah. Birokrasi \& Politik. Jakarta: PT RajaGrafindo Persada. 2007

Tim Dosen Ap. Manajemen Pendidikan. Yogyakarta: UNY Press. 2011

Unger, Jean-Pierre et al. "Through Mintzberg s glasses: a fresh look at the organization of ministries of health." Bulletin of the World Health Organization. 78(8) 2000. pp: 1005-1014.

Widaningrum, Ambar. Reformasi Manajemen Pelayanan Kesehatan, dalam Pramusinto dan Purwanto (ed). Reformasi Birokrasi, Kepemimpinan, dan Pelayanan Publik: Kajian tentang pelaksanaan otonomi daerah di Indonesia. Yogyakarta; Gaya Media. 2009

Winardi, J. Teori Organisasi dan Pengorganisasian. Jakarta: Raja Grafindo Persada. 2003. Cet. 1 
Endah Winarti

Xi, Youmin and Xiaojun Zhang. "Replying to management Challenges: Integrating oriental and occidental wisdom by HeXie Management Theory", Chinese Management Studies, Vol. 6 (3) 2012. pp. 395-412. Emerald Group Publishing Limited. https://doi.org/10.1108/17506141211259104

Tarbiyatuna: Jurnal Pendidikan Ilmiah Vol. 5 No. 1 (Juni) 2020| 76 